Review Article

\title{
Sustainable Tourism: Conceptual Clarity and Contextualization in Nepal
}

\author{
Biranji Gautam \\ Associate Professor \\ Janapriya Multiple Campus, Pokhara, Nepal \\ Corresponding email: biranjigautam@gmail.com
}

Article History

Received 18 April 2021

Revised 23 September 2021

Accepted 13 November 2021

\begin{abstract}
Considering the paucity of empirical research, the purpose of the paper is to communicate the conceptual facets and empirical frameworks of sustainable tourism that can be contextualized in the context of Nepal. This paper is an analytical review, building on previous view. Empirical evidences, Systematic open discourse among stakeholders, Pragmatism Philosophy, Sustainable Mindset, Destination exploration and branding, Industry-Community-Government interrelationship, learning from best practices are prerequisites of initiating and implementing sustainable tourism practices in Nepal. Sustainability tourism is result of continuous efforts. The academic and business model depends upon context and mindset. This study attempts to offer some empirical models that can be contextualized in Nepalese context. In Nepalese context, revival and exploration of new destinations is needed before sustainability dimension. The research paper has suggested some of the research issues and models in which future research on Nepalese perspective could be conducted. Moreover, study has disseminated contextual remedies for initiating and implementing sustainable tourism scenario in Nepal.
\end{abstract}

Keywords: Destination branding, destination exploration, sustainable tourism, tourism destination

\section{INTRODUCTION}

Nepal is in need of developing and maintaining its unique position in global tourism industry through the means of sustainable tourism initiatives and implementation. Destination

(C) The Author, published by JRCC, Janapriya Multiple Campus. 
exploration and branding decisions should entail sustainability issues. Ahead of it, stakeholders involved in tourism and hospitality sector must possess sustainable mindset to enhance tourism sector in Nepal assuming that intention is antecedent for behavior. Sustainable tourism development incorporates economic, environmental and socio-cultural dimension characterized in consistent with theory of sustainable development. The concept of sustainable tourism was based on the need to minimize the negative impact of tourism on natural and cultural resources.

According to economic impact report published by World Travel and Tourism Council [WTTC], Tourism accounted for $10.3 \%$ of global GDP. While the global economy grew by $2.5 \%$, Travel and Tourism grew significantly more at 3.5\%. Nepal is a country with great potential in global tourism industry. Geographically, it is a country of Asia, lying along the southern slopes of the Himalayan mountain ranges. It is a landlocked country located between India to the east, south, and west and the Tibet Autonomous Region of China to the north. Its territory extends roughly 500 miles (800 kilometres) from east to west and 90 to 150 miles from north to south. About 75 percent of the country is covered by mountains.

From the south to the north, Nepal can be divided into four main physical belts, each of which extends east to west across the country. These are, first, the Tarai, a low, flat, fertile land adjacent to the border of India; second, the forested Churia foothills and the Inner Tarai zone, rising from the Tarai plain to the rugged Mahabharat Range; third, the mid-mountain region between the Mahabharat Range and the Great Himalayas; and, fourth, the Great Himalaya Range, rising to more than 29,000 feet (some 8,850 meters). (Britannica, 2021)

The country possesses 8 of 10 highest mountains in the world. It is a hotspot destination for mountaineers, rock climbers and people seeking adventures. With 15 National and Wildlife Parks(two are UNESCO Heritage Sites) Nepal is one of the last places on earth to spot the Asiatic rhinoceros and the Royal Bengal Tiger. Likewise, rich in ancient culture and tradition, landscape, people internalized with hospitable culture would be key positioning ingredients in global tourism diaspora. Some of the tourism attractions of the country are wilderness tourism, religious sites, cultural and heritage sites, mountain climbing, trekking, bird watching, rafting/ kayaking/canyoning, hot air ballooning, bungee jumping, paragliding, ultralight aircraft, mountain biking, jungle safari, mountain flight and rock climbing. (NTB, 2019).

Buttler (1993) argued sustainable tourism is a form of tourism that can maintain its viability in an area for an indefinite period of time. Considering this definition, there are many popular tourism destinations in Nepal which have been reached to decline stage of Tourist 
Destination Life Cycle. Either, they need to be re-innovated or new destinations need to be explored and developed by incorporating sustainability dimensions. Sustainability in Nepal should be defined in participatory triple helix approach whereby tourism entrepreneurs, tourist, destination community need to identify the contextual elements of sustainability measures guided by theory, development and best practices of sustainability around the globe. Based on this notion, the primary approach in sustainable tourism development of a destination is the identification of stakeholders and then comprehending their concerns in tourism planning and development (Mohaidin, Wei, \& Murshid, 2017).

\section{CONTEXTUALIZATION}

First and Foremost, one of the areas of empirical assessment in sustainable tourism research would be analysis of tourist intention in particular tourist destination of country or country as a whole. Such studies shall contribute to understanding the behavioral intention of visitors that is crucial for tourism planning and marketing, specifically in the sustainable selection of travel destinations.

Based on the framework developed by Mohaidin, Wei, and Murshid (2017), the items of research instrument have been operationalized into Nepalese Context. As extensively used framework, this framework based on theory of planned behavior, theory of reasoned action or other comprehensive theories related to behavioral intentions is equally relevant in goal directed behavior of tourist in contemporary Nepalese context.

\section{Table 1}

Construct of Sustainable Tourism Based on the Framework of Mohaidin Wei and Murshid (2017)

\begin{tabular}{|c|c|c|}
\hline Constructs & $\begin{array}{l}\text { Nature of } \\
\text { Variable }\end{array}$ & Measurement Items \\
\hline $\begin{array}{l}\text { Intention to } \\
\text { select sustainable } \\
\text { tourist destination } \\
\text { (ISTD) }\end{array}$ & $\begin{array}{l}\text { Dependent } \\
\text { variable }\end{array}$ & $\begin{array}{l}\text { I plan to pursue environmentally sustainable activities (e.g., } \\
\text { Energy conservation, recycling) in the future. } \\
\text { I plan to support environmental initiatives and visit the sustainable } \\
\text { tourism site in the future. } \\
\text { In the future, I intend to seek out ways to support and promote } \\
\text { sustainable approach in tourism. } \\
\text { I do NOT want to support environmentally sustainable activities in } \\
\text { the future. (R) } \\
\text { I plan to play a part in reducing harm to the environment in the } \\
\text { future at the sustainable tourism destination. }\end{array}$ \\
\hline
\end{tabular}




\begin{tabular}{|c|c|c|}
\hline $\begin{array}{l}\text { Environmental } \\
\text { Attitudes (ENA) }\end{array}$ & $\begin{array}{l}\text { Independent } \\
\text { Variable }\end{array}$ & $\begin{array}{l}\text { I would be very sad if local cultures in Nepal would lose some of } \\
\text { their originality because of tourism development. } \\
\text { It is important to protect the environment. } \\
\text { In my opinion, it is important to conserve the natural resources. } \\
\text { I am concerned about long-term of the environment. }\end{array}$ \\
\hline Motivation(M) & $\begin{array}{l}\text { Independent } \\
\text { Variable }\end{array}$ & $\begin{array}{l}\text { I want to travel to somewhere in an eco-environment. } \\
\text { I want to learn something new and interesting. } \\
\text { I want to see how other people live and their way of sustained life. } \\
\text { I want to experience different cultures that are different from mine. } \\
\text { I want to travel to a destination that I have never visited before and } \\
\text { escape from my daily life. }\end{array}$ \\
\hline Destination & Independent & The accommodation facilities in Nepal are sufficient. \\
\hline Image (DES) & Variable & $\begin{array}{l}\text { Nepal has rich and quality leisure facilities. } \\
\text { The environment in Nepal is orderly, clean and hygiene. } \\
\text { In Nepal, the natural environment is protected in a good way. } \\
\text { Nepal is a global brand in tourism. } \\
\text { Tourism in Nepal is well planned. } \\
\text { Nepal offers historical and cultural attractiveness. } \\
\text { Nepal has wide variety of local food and beverages. } \\
\text { Nepalese people are helpful and hospitable. }\end{array}$ \\
\hline $\begin{array}{l}\text { Word of Mouth } \\
\text { (WOM) }\end{array}$ & $\begin{array}{l}\text { Independent } \\
\text { Variable }\end{array}$ & $\begin{array}{l}\text { I speak favorably about Nepal as a tourism destination to people } \\
\text { that I know. } \\
\text { I bring up Nepal as a tourism destination in a positive way in } \\
\text { conversation I have with friends and acquaintances. } \\
\text { In a social situation, I speak favorably about Nepal as a tourism } \\
\text { destination. } \\
\text { I recommend Nepal as a tourism destination for family/friends. } \\
\text { When some of my family/friends were considering a good } \\
\text { destination, I suggested Nepal. } \\
\text { I will offer all the information needed to have a good time in } \\
\text { Nepal. } \\
\text { I will lead tours for them. } \\
\text { I will show them all the good stuff in Nepal. }\end{array}$ \\
\hline
\end{tabular}




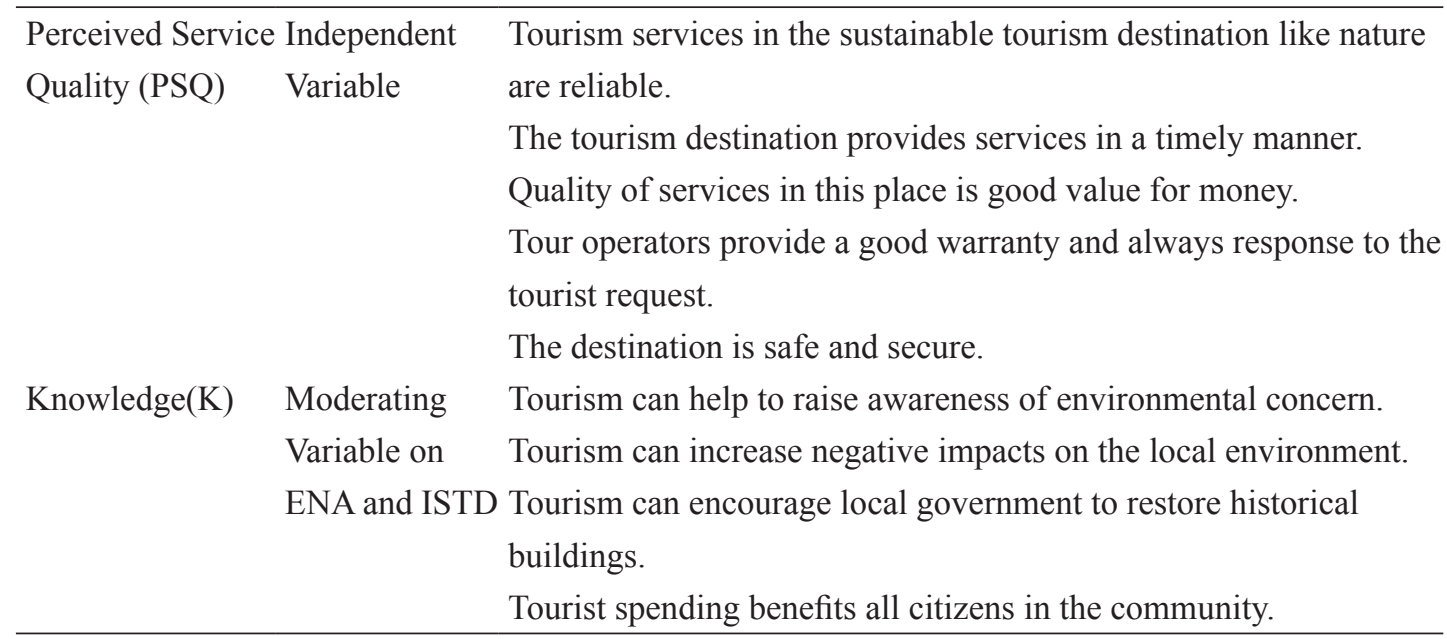

Secondly, adopting the framework of Garg and Pandey (2020) that has applied the value-belief-norm model (VBN) which is blend of two theories i.e., values theory and norms activation theory, Nepalese empirical study on sustainable tourism could be based on examining the mediating role of personal norms in determining the intention to adopt sustainable tourism in Nepal. Furthermore, the direct effect of perceived consumer effectiveness and consumer knowledge can also be examined by using structural equation modeling and operationalized using following research framework, construct and measurement items. Furthermore, previous researches have also contributed into development and validation of research instrument to measure residents' attitude towards sustainable tourism (Boselli, Caravello, Scipioni, \& Baroni, 1997).

\section{Table 2}

Construct of of Sustainable Tourism Based on the Framework Garg and Pandey (2020)

Constructs Measurement Items

Consumer Knowledge I am quite familiar with sustainable tourism.

I know quite a lot about sustainable tourism.

I have often read articles or news about or have learned about sustainable tourism. 


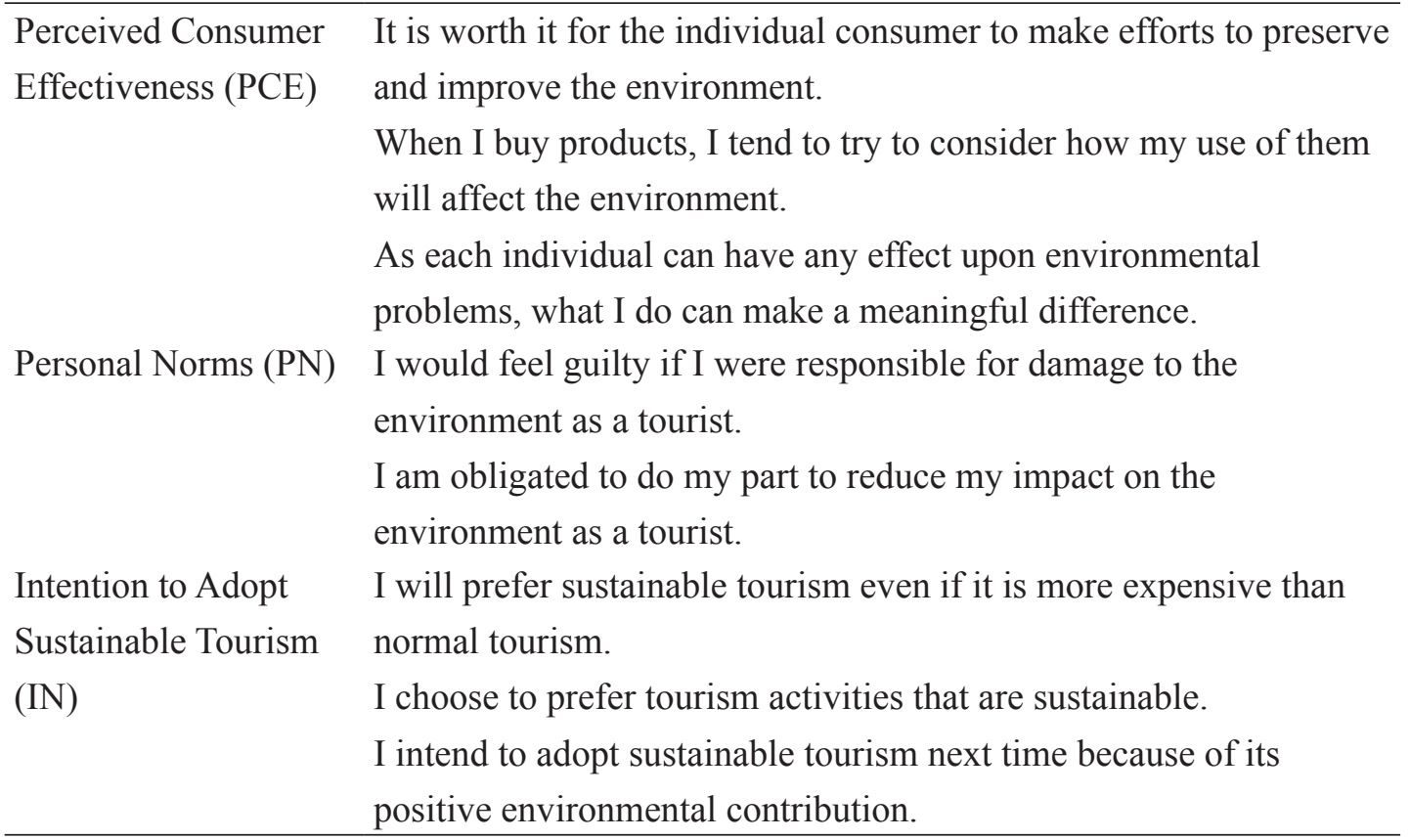

\section{CONCLUSION}

The study has attempted to present pre-established research frameworks for empirical inquiry in Nepalese context. There seems to be dearth of empirical investigation regarding sustainable tourism development in Nepal and though the presented models can be used, it is still highly important to develop our own research instrument through pragmatism approach which will help to provide justice to national tourism development. Sustainable development has been an important strategy promoted by the United Nations World Tourism Organization (UNWTO) and governments of many destinations. Even though the above presented models on empirical research can help to extract important findings in Nepalese context. It should not be forgotten that sustainable tourism requires sustainable mindset of stakeholders involved in tourism consumption, promotion and regulation. Therefore, Nepal has a challenge to promote tourism that does not consume nature. Boselli, Caravello, Scipioni and Baroni (1997) has advocated how Nepal can achieve tourism sustainability. Nepal needs to plan touristic development by reducing touristic pressure in few areas, extend the protected surface with the constitution of new traditional parks and reserves, control the impact of tourism on the local population in the decisions concerning touristic development, promote the participation of population in the decisions concerning touristic development, transmit the younger 
generations the values and traditional practices so that they may be respected and maintained, critical acquisition of cultural and economic models of other countries that have to be adapted to the traditions and local technologies capacity, education of tourist and operators who must be taught to respect the natural and cultural beauty of Nepal, develop integrated projects for the development of alternative energy to the use of wood, such as sun, wind and hydroelectric power.

\section{REFERENCES}

Boselli, A., Caravello, G., Scipioni, A., \& Baroni, A. (1997). Sustainable tourism development in Nepal: Evaluation and perspectives. Journal of Human Ecology, 8 (1), 1-12. doi:10. 1080/09709274.1997.11907229

Choi, H. C., \& Sirakaya, E. (2005). Measuring residents' attitude toward sustainable tourism: Development of sustainable tourism attitude scale. Journal of Travel Research, 43 (4), 380-394. doi:10.1177/0047287505274651

Garg, P., \& Pandey, A. (2020). Towards sustainable tourism: An empirical investigation. Foresight, Ahead-of-print (Ahead-of-print). doi:10.1108/fs-04-2020-0042

Mackenzie, N., \& Gannon, M. J. (2019). Exploring the antecedents of sustainable tourism development. International Journal of Contemporary Hospitality Management, 31 (6), 2411-2427. doi:10.1108/ijchm-05-2018-0384

Mohaidin, Z., Wei, K. T., \& Murshid, M. A. (2017). Factors influencing the tourists' intention to select sustainable tourism destination: A case study of Penang, Malaysia. International Journal of Tourism Cities, 3 (4), 442-465. doi:10.1108/ijtc-11-2016-0049

Ruhanen, L., Moyle, C., \& Moyle, B. (2019). New directions in sustainable tourism research. Tourism Review, 74 (2), 138-149. doi:10.1108/tr-12-2017-0196

Timur, S., \& Getz, D. (2009). Sustainable tourism development: How do destination stakeholders perceive sustainable urban tourism? Sustainable Development, 17 (4), 220-232. doi:10.1002/sd.384

Yu, C., Chancellor, H. C., \& Cole, S. T. (2009). Measuring residents' attitudes toward sustainable tourism: A reexamination of the sustainable tourism attitude scale. Journal of Travel Research, 50 (1), 57-63. doi:10.1177/0047287509353189

Zhang, S., \& Chan, E. S. (2019). A modernism-based interpretation of sustainable tourism. International Journal of Tourism Research, 22 (2), 223-237. doi:10.1002/jtr.2330

Zhu, L., Zhan, L., \& Li, S. (2020). Is sustainable development reasonable for tourism destinations? An empirical study of the relationship between environmental competitiveness and tourism growth. Sustainable Development. doi:10.1002/sd.2131. 